\title{
Effect of Raspberry bushy dwarf virus, Raspberry leaf mottle virus, and Raspberry latent virus on Plant Growth and Fruit Crumbliness in 'Meeker' Red Raspberry
}

Diego F. Quito-Avila, Centro de Investigaciones Biotecnologicas del Ecuador, Escuela Superior Politecnica del Litoral, CIBE-ESPOL, Plant Pathology-Virology, Guayaquil, Ecuador; and Danielle Lightle and Robert R. Martin, Horticultural Crops Research Laboratory, United States Department of Agriculture-Agricultural Research Service, Corvallis, OR 97330

\begin{abstract}
Quito-Avila, D. F., Lightle, D., and Martin, R. R. 2014. Effect of Raspberry bushy dwarf virus, Raspberry leaf mottle virus, and Raspberry latent virus on plant growth and fruit crumbliness in 'Meeker' red raspberry. Plant Dis. 98:176-183.

Raspberry crumbly fruit in red raspberry (Rubus idaeus), widespread in the Pacific Northwest of the United States and British Columbia, Canada, is most commonly caused by a virus infection. Raspberry bushy $d$ warf virus (RBDV) has long been attributed as the causal agent of the disease. Recently, the identification of two additional viruses, Raspberry leaf mottle virus (RLMV) and Raspberry latent virus (RpLV), in northern Washington and British Columbia, suggested the existence of a possible new virus complex responsible for the increased severity of the disease. Virus testing of crumbly fruited plants from five fields in northern Washington revealed the presence of RLMV and RpLV, in addition to RBDV. Plants with less severe crumbly fruit symptoms had a much lower incidence of RLMV or RpLV. Field trials using replicated plots of 'Meeker' plants containing single and mixed infections

of RBDV, RLMV, or RpLV, along with a virus-free control, were developed to determine the role of RLMV and RpLV in crumbly fruit. Field evaluations during establishment and two fruiting years revealed that plants infected with the three viruses or the combinations $\mathrm{RBDV}+\mathrm{RLMV}$ and $\mathrm{RBDV}+\mathrm{RpLV}$ had the greatest reduction in cane growth, or fruit firmness and fruit weight, respectively. Quantitative reverse transcription-polymerase chain reaction (RT-PCR) showed that the titer of RBDV was increased $\sim 400$-fold when it occurred in mixed infections with RLMV compared to RBDV in single infections. In addition, a virus survey revealed that RLMV and RpLV are present at high incidence in northern Washington; whereas the incidence in southern Washington and Oregon, where crumbly fruit is not as serious a problem, was considerably lower.
\end{abstract}

Virus complexes involving two or more virus species infecting the same host are found commonly in nature and often result in synergistic interactions that lead to more severe diseases in plants $(10,39,40)$. A common type of synergism is the increase in accumulation of one or more viruses in a mixed infection relative to each virus alone $(3,14,25,26,31,42)$. This phenomenon is sometimes related to the presence of virus-encoded RNA-silencing suppressors that counteract the plant defense mechanism, allowing a second virus to accumulate in the plant at higher levels relative to single infections $(4,26,40,41)$. Other types of viral-synergistic interactions result in more efficient virus movement through a plant, transmission by a new vector, or infection of a formerly nonhost plant $(1,5,7,8,44)$.

Several cases have been reported where viral complexes result in increased severity of diseases in crop plants. Virus yellows disease in sugar beet has been shown to be caused by a synergistic interaction between Beet yellows virus (BYV), genus Closterovirus, and Beet western yellows virus (BWYV), genus Polerovirus (43). García-Cano et al. (11) showed that mixed infections of the crinivirus Tomato chlorosis virus (ToCV) and the tospovirus Tomato spotted wilt virus (TSWV) resulted in resistance breakdown when TSWV-

Corresponding author: D. F. Quito-Avila,

E-mail: diego.quito.avila@gmail.com

The USDA is an equal opportunity provider and employer.

Accepted for publication 22 August 2013.

http://dx.doi.org/10.1094/PDIS-05-13-0562-RE

This article is in the public domain and not copyrightable. It may be freely reprinted with customary crediting of the source. The American Phytopathological Society, 2014. resistant plants were preinfected with ToCV. Corn lethal necrosis disease was shown to be caused by co-infection with Maize chlorotic mottle virus (MCMV) and either Wheat streak mosaic virus (WSMV) or Maize dwarf mosaic virus (MDMV) $(23,34)$. Similarly, the interaction between Cucumber mosaic virus (CMV) and Zucchini yellow mosaic virus (ZYMV) in zucchini squash plants $(5,42)$, or Sweet potato feathery mottle virus (SPFMV) and Sweet potato chlorotic stunt virus (SPCSV) in sweet potatoes (15), resulted in more severe symptoms.

In Rubus, Blackberry yellow vein disease (BYVD)—originally associated with Tobacco ringspot virus (TRSV) and later with Blackberry yellow vein associated virus (BYVaV)—was found to be the result of a multiple-virus infection. However, mixed infections involving BYVaV and Blackberry virus $Y$ (BVY) turned out to be the most critical combination, resulting in severe leaf vein yellowing and, in some cases, plant death $(19,36,37)$. Raspberry mosaic disease (RMD) and Black raspberry decline (BRD) are two other examples of disorders caused by virus complexes in Rubus. RMD was first reported in the 1920s and is likely caused by combinations of at least three viruses including Black raspberry necrosis virus (BRNV), Rubus yellow net virus (RYNV), and Raspberry leaf mottle virus (RLMV) $(13,20,38)$. BRD has become a serious problem in Oregon, where most black raspberries are produced in the United States. Although the disease is attributed to a viral complex, BRNV has been hypothesized to play a major role in symptom development $(13,19)$.

During the last two decades, red raspberry production in the Pacific Northwest (PNW) (Oregon and Washington in the United States, and British Columbia, Canada) has been severely affected by crumbly fruit, a virus-induced disease widespread in areas planted with the susceptible cultivar Meeker, as well as several other cultivars. Symptoms include drupelet abortion that causes the fruit to crumble at harvest, resulting in significant reductions of 
yield and fruit quality $(9,21)$. The crumbly fruit disorder in Meeker has long been attributed to Raspberry bushy dwarf virus (RBDV), a pollen-and seed-borne Idaeovirus that is found in most, if not all, raspberry production areas around the world $(6,19,21)$. Recently, two viruses, RLMV (Closterovirus, family Closteroviridae) $(20,38)$ and Raspberry latent virus, RpLV (unassigned genus, family Reoviridae) $(28,29)$, both transmitted by the large raspberry aphid Amphorophora agathonica Hottes, have been detected at high incidence in areas where crumbly fruit is more prevalent. This finding suggested the existence of a new viral complex responsible for the increased severity of crumbly fruit and yield decline in Meeker (27).

This communication presents data from experiments conducted to study the effect of single and mixed infections of RBDV, RLMV, and RpLV on plant growth and fruit crumbliness in Meeker red raspberry.

\section{Materials and Methods}

Virus isolates, plant material, and planting location. A total of 90 root cuttings randomly chosen from 2- to 3-year-old Meeker raspberry plantings were obtained from production fields in northern Washington State. The roots were planted and grown in a greenhouse under standard conditions (12 to $16 \mathrm{~h}$ daylight at $25^{\circ} \mathrm{C}$ ). Plants were tested for known Rubus viruses either by polymerase chain reaction (PCR) or enzyme-linked immunosorbent assay (ELISA). Singly infected plants were used to generate seven virus-infected treatments (RBDV, RLMV, RpLV, RBDV+RLMV, RBDV+RpLV, RLMV+RpLV, and RBDV+RLMV+RpLV) by graft inoculations in Meeker. A virus-free treatment (control) was also included. Five weeks postinoculation, the plants were tested by reverse transcription (RT)-PCR to confirm their virus-infected or virus-free status. Plants infected with the virus or virus combination of interest were transplanted to 1-gal pots and maintained in the greenhouse. The propagation period lasted from October 2009 to April 2010.

After 3 weeks of outdoor acclimation, the plants were planted in the field at Washington State University's Northwestern Research and Extension Center (Mt. Vernon) in May 2010. The experiment was established using a randomized complete block design. Each block consisted of plots containing five plants $(0.8 \mathrm{~m}$ apart $)$ of the same treatment. Treatment plots were randomly arranged across six blocks (replicates) (3 m apart). In order to avoid RLMV and RpLV cross-contamination between treatments, the plants were treated with systemic insecticides for aphid control (thiamethoxam and acetamiprid) during the months of May, July, and September each year of the study.

Plant growth and crumbly fruit assessment. The effects of single and mixed infections of RBDV, RLMV, and RpLV on plant growth and fruit crumbliness were evaluated in the field in 2010 (establishment year) through 2012. To assess plant growth, the height and diameter of the longest primocane (diameter measured at $10 \mathrm{~cm}$ aboveground) was measured each growing season (September 2010, and July 2011 and 2012).

Fruit was hand harvested separately from each block on 13 and 21 July 2011 and 7, 14, and 21 July 2012. Fruit weight was obtained by averaging random subsamples of 50 berries from each plot at each harvest. Firmness, measured as the force (in grams) necessary to close the receptacle cavity, was determined from 10 berries subsampled from the 50 berry fruit weight pool using a mechanical force gauge (AMETEK, Hunter Spring, Harrisburg, PA) (2). The number of drupelets (seeds) per berry was determined from a random subsample of 15 berries per plot. Berries were squashed and submerged in a pectinase solution (Pectinex Smash, Novozymes A/S, Bagsvaerd, Denmark) overnight at room temperature. Seeds were then sieve-washed, dried, and counted.

In addition, the severity of crumbly fruit was evaluated using a 0 to 3 rating system $(0=$ no crumbly fruit, $1=$ mild, $2=$ medium, and 3 = severely crumbled).

Data analysis. Each year plant growth characteristics (cane height and diameter) and fruit characteristics (drupelet counts, fruit weight, and fruit firmness) were analyzed separately. Data were analyzed using factorial analysis to test for significant interactions among the three viruses. Plant growth models included block as a random factor. Fruit character models were analyzed using a repeated measures model because of multiple harvests taken each year. Significant interaction terms indicate that virus effects are not independent of each other (17). Reported $P$ values and standard errors were adjusted using Tukey's honestly significant difference to correct for multiple comparisons. All statistics were calculated using PROC GLIMMIX (33).

To evaluate the nature of virus interactions (synergistic or antagonistic), Abbott's equation for synergy was used, following the approach of Murphy and Bowen (22). When an interaction term was significant, the percent reduction in the measured parameter (e.g., cane height) caused by that treatment was calculated compared to the virus-free control (observed value, $\mathrm{C}_{\mathrm{obs}}$ ), to be compared with the expected value $\left(\mathrm{C}_{\text {exp }}\right)$ if the viruses were acting independently. $\mathrm{C}_{\exp }$ was calculated using the formula:

$$
\mathrm{C}_{\exp }=\mathrm{A}+\mathrm{B}-(\mathrm{AB} / 100)
$$

where $\mathrm{A}$ is the percent reduction of the measured parameter caused by infection with virus $\mathrm{A}$ alone, and $\mathrm{B}$ is the percent reduction of the measured parameter caused by infection with virus $\mathrm{B}$ alone. When $\mathrm{C}_{\mathrm{obs}}>\mathrm{C}_{\text {exp }}$, then the virus interaction was considered to be synergistic with respect to the measured parameter, and when $\mathrm{C}_{\mathrm{obs}}$ $<\mathrm{C}_{\text {exp }}$, the virus interaction was considered to be antagonistic.

RNA extraction and RT-PCR. Approximately $100 \mathrm{mg}$ of each collected leaf was subjected to total RNA extraction following the methodology described by Halgren et al. (13), and modified by Rott and Jelkmann (32). The RNA was resuspended in $150 \mu \mathrm{l}$ of TE. RT reactions were performed using random primers. Two and one-half microliters of the RT product were used as template for the PCR in a final volume of $25 \mu \mathrm{l}$ according to the polymerase manufacturer's instructions (TaKaRa Bio Inc., Shiga, Japan). Primers developed by Tzanetakis et al. (38) and Quito-Avila et al. (28) were employed for detection of RLMV and RpLV, respectively. RBDV was detected by a set of degenerate primers (F: AAAGACKYSCAGAAATCCGTTA and R: TGWAWARGAAGT TDGCCCATTT) (K. Keller, unpublished). The PCR program for amplification of the targets consisted of initial denaturation for 4 min at $94^{\circ} \mathrm{C}$ followed by 40 cycles with denaturation for $40 \mathrm{~s}$ at $94^{\circ} \mathrm{C}$, annealing for $25 \mathrm{~s}$ at $58^{\circ} \mathrm{C}$ for RLMV and $\mathrm{RpLV}$, and $55^{\circ} \mathrm{C}$ for RBDV, and extension for $40 \mathrm{~s}$ at $72^{\circ} \mathrm{C}$, with a final 7-min extension step at $72^{\circ} \mathrm{C}$.

Quantification and comparison of virus levels in single and mixed infections. In order to monitor the virus concentration in plants containing single or mixed infections over time, five plants of each virus treatment were collected from the experiment and tested by TaqMan-based quantitative RT-PCR (qRT-PCR) using the methodology described by Quito-Avila and Martin (30). Leaf sampling was done on a monthly basis (May through October) during the growing seasons of 2010 and 2011. In addition, a greenhouse experiment was conducted to compare changes in virus titers across the treatments under constant conditions $(16 \mathrm{~h}$ daylight at $25^{\circ} \mathrm{C}$ ). To this end, plants containing single infections (RBDV, RLMV, or RpLV) were graft-inoculated with the other virus or healthy tissue (mock inoculation). qRT-PCR was used to compare the titer of each virus in the presence of the inoculated virus(es) with its titer in the mock-inoculated plants. The youngest fully developed leaf was used for RNA extraction on a weekly basis for 7 weeks starting at 10 days post-graft-inoculation.

qRT-PCR data analysis. qRT-PCR data were analyzed by two relative quantification methods: the delta-delta $C t$ method $(\Delta \Delta C t)$, implemented by Applied Biosystems software, and the method developed by Pfaffl (24). Both methods use the amplification of a stable endogenous control to standardize each sample and validate the differences in $C t$ values between two or more samples. In this study, the $\Delta \Delta C t$ method was used as a baseline to detect variations or trends in virus titers across treatments and over time. However, if a significant variation was detected, the Pfaffl equation was ap- 
plied in order to estimate more accurately the amount of viral copies being increased or decreased in a given sample due to the presence of another virus or different sampling dates. A region of the $\mathrm{NAD}(\mathrm{P}) \mathrm{H}$ dehydrogenase subunit $\mathrm{B}(n d h B)$ was used as the endogenous control, as described (30).

Incidence of RBDV, RLMV, and RpLV in raspberry fields in Washington and Oregon. Observations and reports from raspberry growers in the PNW have indicated that crumbly fruit disease and yield decline is more prevalent in the northern production areas compared to southern Washington and Oregon (R. R. Martin, unpublished). To determine whether these observations were related to virus incidence, red raspberry fields ( $n=4$, for each field age) in Washington and Oregon were sampled and tested for RBDV, RLMV, and RpLV in June of 2010. Randomly selected leaf samples from 36 plants per field were used for subsequent RNA extraction and RT-PCR.

Virus survey from crumbly fruited plants. During the fruiting season of 2011, a crumbly fruited plant survey was conducted in five 4- to 7-year-old commercial raspberry fields in northern Washington. The severity of crumbly fruit was evaluated using the 0 to 3 rating system as described above. While the focus was on RBDV, RLMV, and RpLV, the nepoviruses Tomato ring spot virus (ToRSV) and Tobacco ring spot virus (TRSV) were also tested for, as they have been reported to occur, though less commonly in the
PNW (18). Thirty-six plants showing crumbly fruit were leaf-sampled from each field, rated for symptom severity, and tested for viruses.

\section{Results}

Effect of RBDV, RLMV, and RpLV on primocane growth. Virus treatments significantly decreased primocane height compared to healthy canes. All singly infected treatments reduced primocane height relative to the control. However, the greatest reductions in height were in the treatments RBDV+RLMV, $\mathrm{RBDV}+\mathrm{RpLV}$, and RBDV+RLMV+RpLV. Effects were most pronounced during the establishment year (2010). However, reduced height was consistently observed during 2011 and 2012 (Fig. 1A, Fig. 2).

Similar to primocane height, differences in cane diameter were largest in 2010. However, only smaller reductions in diameter were measured in 2011 and 2012 (Fig. 1B). RLMV and all combinations of co-infections exhibited the thinnest canes in 2010; while in 2011, the smallest cane diameters were found in all co-infection treatment combinations. No significant differences in cane width were attributable to virus infection in 2012 (Fig. 1B).

Effect of RBDV, RLMV, and RpLV on fruit quality. Virus infections resulted in significant reductions in berry weight in 2011 and 2012. In 2011 and 2012, the lowest berry weights were rec-
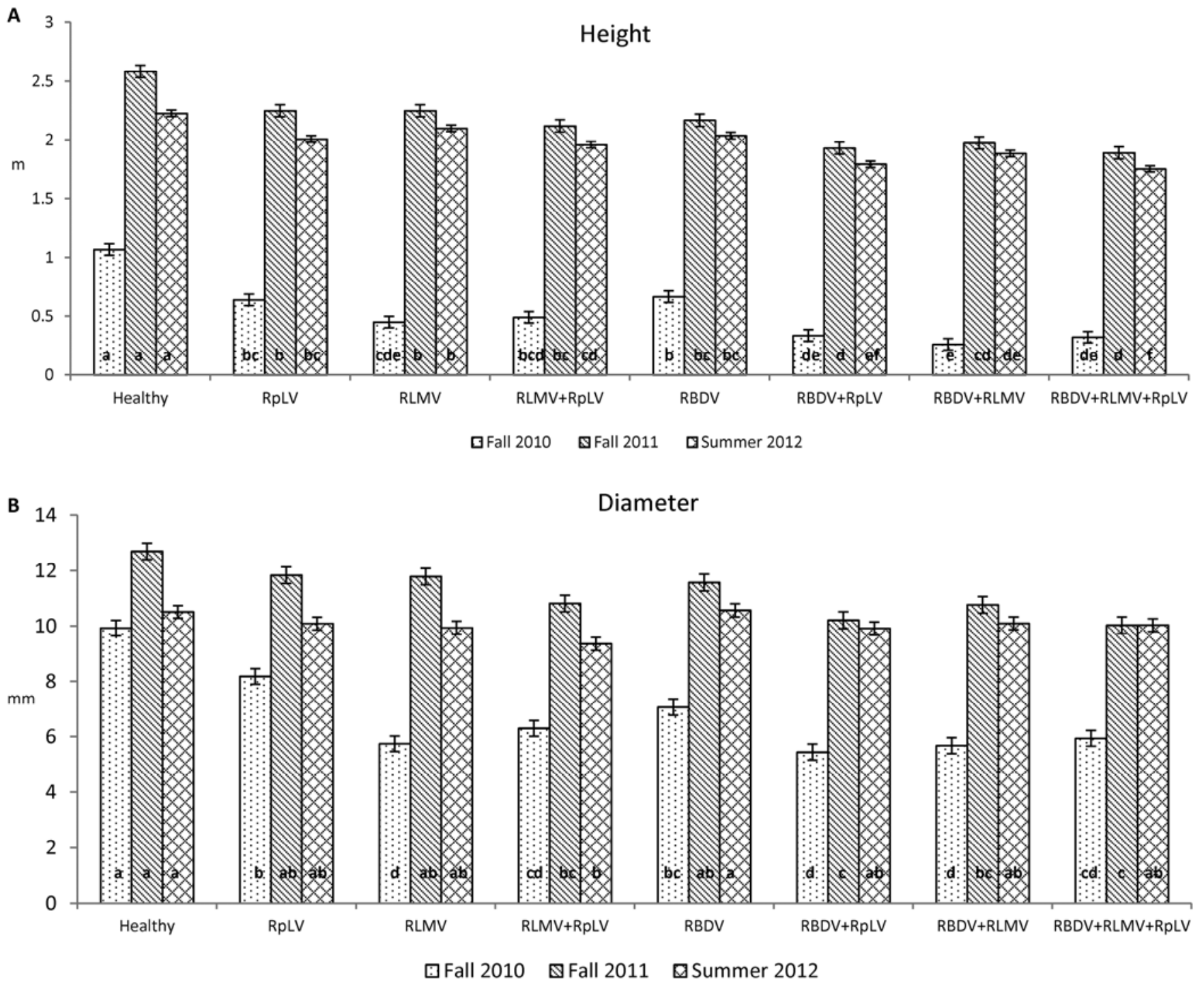

(continued on next page)

Fig. 1. Effect of Raspberry bushy dwarf virus (RBDV), Raspberry latent virus (RpLV), and Raspberry leaf mottle virus (RLMV), in single or mixed infections, on A, height, $\mathbf{B}$, diameter, C, fruit weight, D, drupelet count, and E, fruit firmness. Combined abbreviations indicate mixed infections. Virus-free treatment is denoted as healthy. 
orded in treatments RBDV+RpLV and RBDV+RLMV+RpLV (Fig. 1C). Single infections of RLMV and RpLV also had significantly lower berry weight than the virus-free control in both years (Fig. $1 \mathrm{C})$.
For fruit firmness, the lowest values (which correspond to the softest fruit) were in treatments RBDV, RBDV+RpLV, and RBDV+RLMV+RpLV in 2011 and 2012 (Fig. 1D). There were no significant differences in firmness between the uninfected controls
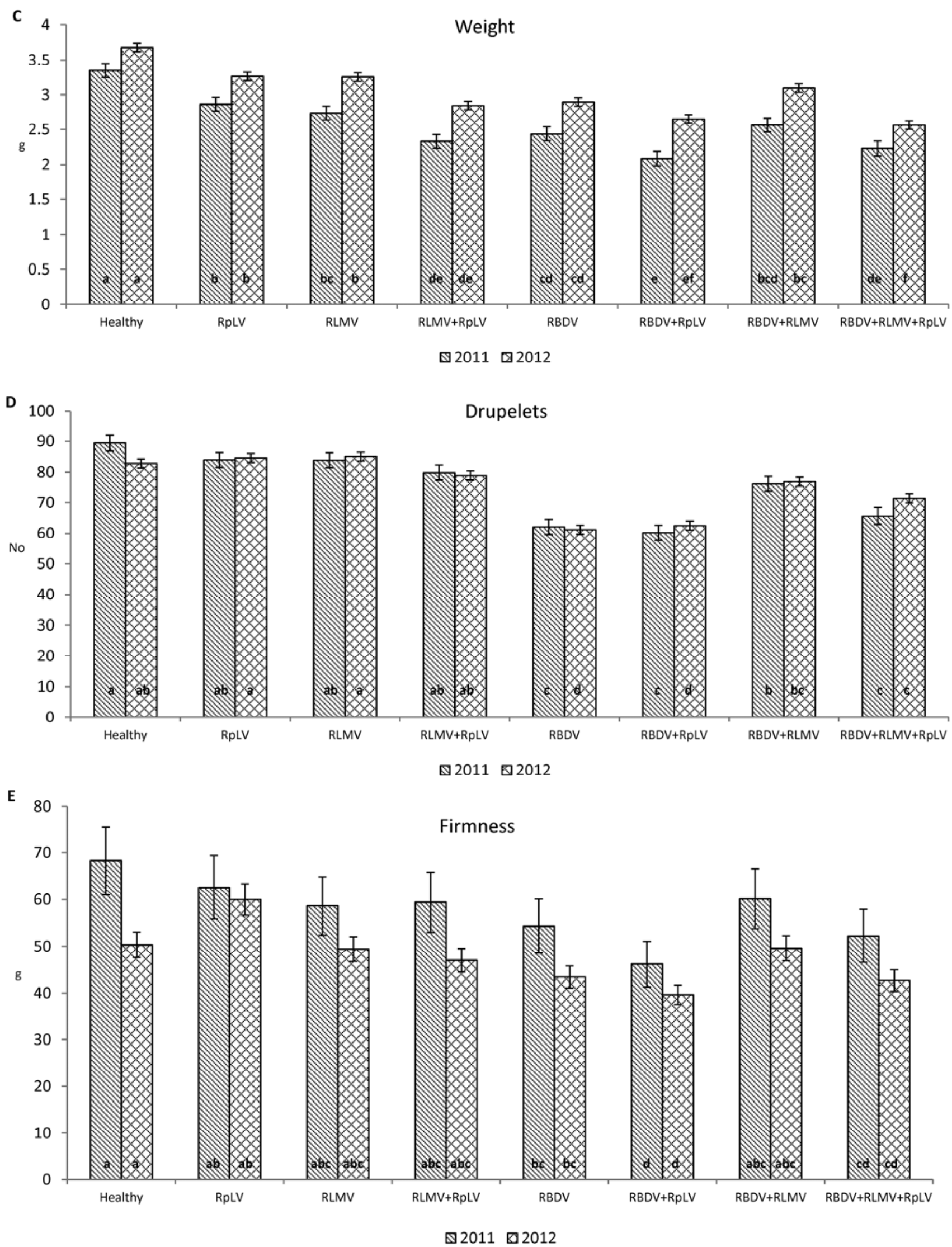

Fig. 1. (continued from previous page) 
and plants singly infected with RpLV or RLMV in either year (Fig. 1D). In both years, drupelet counts per berry were lowest in RBDV, RBDV+RpLV, and RBDV+RLMV+RpLV treatments (Fig. 1E).

Virus interactions in symptom expression. All virus combinations causing significant plant growth and yield effects were examined to determine whether the interaction was synergistic or antagonistic for each measured parameter. Only two interactions were found where the viruses were acting synergistically to enhance growth and yield reduction. During the establishment year (2010), primocane height of RBDV+RLMV-infected plants was significantly shorter than expected based on the observed height reduction by RLMV alone and RBDV alone (Table 1). There was also a synergistic interaction between RBDV and RpLV on fruit firmness in 2011, with fruits in the treatment RBDV+RpLV significantly less firm than would be expected if the viruses were acting independently (Table 1). However, in 2012 the same virus combination resulted in an antagonistic interaction increasing fruit firmness (Table 1).

Other antagonistic interactions involved the combination RBDV+RLMV, where fruit symptoms observed in this mixed infection were less severe than would be expected if RBDV and RLMV were acting independently. Likewise, fruit quality was not as impacted by the combination RpLV+RLMV as would be expected. Fruit firmness and seed counts were less affected than expected in 2012 (Table 1).

Virus titers under greenhouse conditions. qRT-PCR was used to compare the titer of each virus (RBDV, RLMV, or RpLV) in plants that were later inoculated with a secondary virus with the titer of the same virus in plants that were mock-inoculated. The comparison was done on a weekly basis over a period of 10 weeks. There were no changes in titer for RLMV or RpLV in the presence of a secondary virus. However, $C t$ values for RBDV in co-infections with RLMV were 11 to 13.5 times lower compared to those from RBDV singly infected plants 7 weeks post-graft-inoculation. The Pfaffl equation indicated that the 11 to 13.5 difference in $C t$ values was equivalent to an increase in the titer of RBDV of ap- proximately 400-fold in host plants co-infected with RLMV, or RLMV and RpLV, as previously reported (30).

Virus titers under field conditions. Monitoring of virus titers was made comparing single and mixed infections and sampling at various times across the growing season. The first comparison, performed within a treatment throughout the growing season, showed that the concentration of RpLV and RBDV in singly or mixed-infected plants did not change throughout the season. RLMV titers, on the other hand, showed a 22-fold increase in August compared to the initial virus titer quantified in May (not shown). This increase was observed in single and mixed infected treatments. The second comparison, across treatments at each sampling time, reproduced the results obtained under greenhouse conditions, where RBDV titer was increased 400-fold when in combination with RLMV, or RLMV and RpLV.

RBDV, RLMV, and RpLV incidence in fields in Washington and Oregon. Virus monitoring in raspberry fields in Washington and Oregon in June of 2010 revealed that virus incidence varied across field locations and age of plantings. In northern Washington, RLMV was detected in $96 \%$ of the surveyed fields with an incidence up to $58 \%$ in 2-year-old fields and as high as $100 \%$ in 5year-old fields. RpLV was found in $50 \%$ of the tested fields in northern Washington, with an incidence up to $21 \%$ in 2 -year-old fields and as high as $63 \%$ in 5-year-old fields.

In southern Washington and Oregon, the incidence of RLMV and RpLV in 7-year-old fields ranged from 19 to $40 \%$ and 17 to $20 \%$, respectively. RBDV was present in $100 \%$ of the surveyed fields in Washington and Oregon where at least two fruiting seasons had occurred. Table 2 shows the values for virus incidence obtained from different fields in Washington and Oregon.

Virus survey from crumbly fruited plants. Virus evaluations in northern Washington during the fruiting season of 2011 revealed that in fields with severe crumbly fruit, the incidence of RBDV, RLMV, and RpLV ranged from 92 to $100 \%, 96$ to $100 \%$, and 7 to $40 \%$, respectively. A 4-year-old field with sampled plants showing mild crumbly fruit showed lower virus incidence for RLMV (25\%)

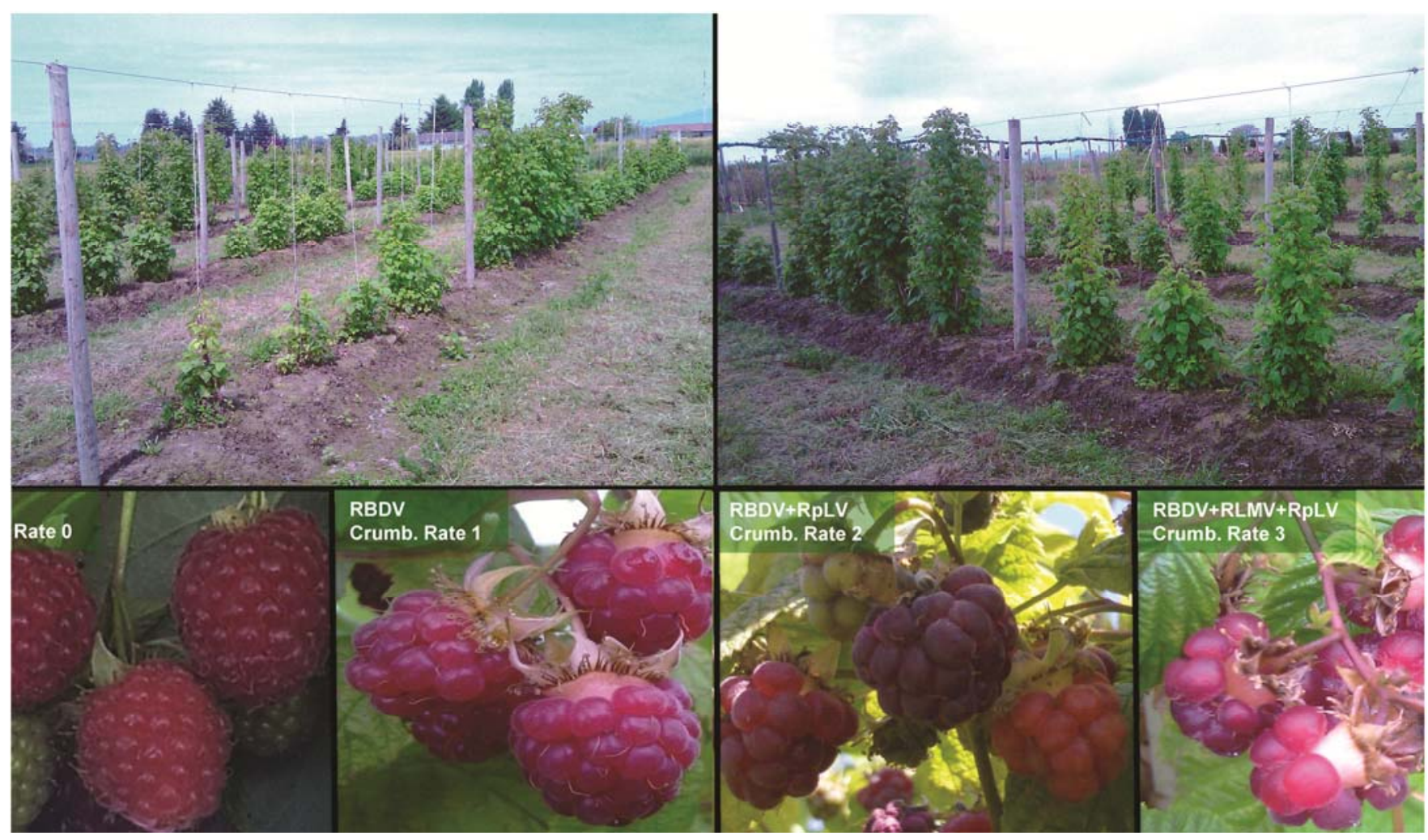

Fig. 2. Upper panel: differences in primocane growth at the end of the planting year (October 2010). Lower panel: Crumbly fruit symptoms observed in plants co-infected with the Raspberry bushy dwarf virus (RBDV); Raspberry latent virus (RpLV); and/or Raspberry leaf mottle virus (RLMV). Normal fruit from a healthy treatment is also shown. Crumbliness (Crumb.) rates are shown next to each treatment. 
and no infection of RpLV; whereas RBDV was still present in $44 \%$. A low incidence (20\%) was found for ToRSV in only one of the crumbly fruited fields (not shown).

Rating-based assessment of fruit crumbliness. Assessment of fruit crumbliness showed that berries corresponding to treatments $\mathrm{RBDV}+\mathrm{RpLV}$ and $\mathrm{RBDV}+\mathrm{RpLV}+\mathrm{RLMV}$ received a score $=3$ (severely crumbly) during both growing seasons. Plants infected with RBDV alone produced fruits with a more frequent (mode) score $=2$; whereas plants singly infected with RLMV, RpLV, and the mixed infection RBDV+RLMV produced fruits with a more frequent score $=1$. Virus-free control received a score $=0$. Figure 2 shows some examples of fruits with different crumbliness rates.

Table 1. Type of virus interactions and their effect on height, diameter, fruit weight, fruit firmness, and drupelet count ${ }^{\mathrm{a}}$

\begin{tabular}{|c|c|c|c|c|c|c|c|}
\hline Treatment & Healthy & RLMV & RpLV & RBDV & RLMV+RpLV & RLMV+RBDV & RpLV+RBDV \\
\hline Primocane height 2010 (m) & 1.07 & 0.45 & 0.64 & 0.66 & 0.49 & 0.26 & 0.33 \\
\hline $\mathrm{C}_{\mathrm{obs}}$ & 0.00 & 57.90 & 40.18 & 37.74 & 54.15 & 75.71 & 68.78 \\
\hline $\mathrm{C}_{\text {exp }}$ & & & & & 74.81 & 73.79 & 62.76 \\
\hline $\begin{array}{l}\text { Type of interaction } \\
(P \text { value })\end{array}$ & & & & & $\begin{array}{l}\text { Antagonistic } \\
\quad(<0.0001)\end{array}$ & $\begin{array}{c}\text { Synergistic } \\
(0.007)\end{array}$ & $\mathrm{N}$ \\
\hline Primocane height 2011 (m) & 2.58 & 2.25 & 2.25 & 2.17 & 2.12 & 1.97 & 1.93 \\
\hline $\mathrm{C}_{\text {obs }}$ & 0.00 & 12.94 & 12.94 & 16.08 & 17.94 & 23.56 & 25.22 \\
\hline $\mathrm{C}_{\text {exp }}$ & & & & & 24.21 & 26.94 & 26.94 \\
\hline $\begin{array}{l}\text { Type of interaction } \\
(P \text { value })\end{array}$ & & & & & $\begin{array}{l}\text { Antagonistic } \\
(0.004)\end{array}$ & $\mathrm{N}$ & $\mathrm{N}$ \\
\hline Primocane height $2012(\mathrm{~m})$ & 2.23 & 2.10 & 2.01 & 2.04 & 1.96 & 1.89 & 1.79 \\
\hline $\mathrm{C}_{\mathrm{obs}}$ & 0.00 & 5.71 & 9.84 & 8.53 & 12.00 & 15.28 & 19.42 \\
\hline $\mathrm{C}_{\text {exp }}$ & & & & & 14.99 & 13.75 & 17.53 \\
\hline $\begin{array}{l}\text { Type of interaction } \\
(P \text { value })\end{array}$ & & & & & $\begin{array}{r}\text { Antagonistic } \\
(0.0082)\end{array}$ & $\mathrm{N}$ & $\mathrm{N}$ \\
\hline Primocane diameter $2010(\mathrm{~mm})$ & 9.93 & 5.74 & 8.18 & 7.06 & 6.30 & 5.68 & 5.44 \\
\hline $\mathrm{C}_{\mathrm{obs}}$ & 0.00 & 42.20 & 17.63 & 28.91 & 36.59 & 42.85 & 45.23 \\
\hline $\mathrm{C}_{\text {exp }}$ & & & & & 52.39 & 58.91 & 41.45 \\
\hline $\begin{array}{l}\text { Type of interaction } \\
(P \text { value })\end{array}$ & & & & & $\begin{array}{l}\text { Antagonist } \\
\quad(<0.0001)\end{array}$ & $\begin{array}{l}\text { Antagonist } \\
(<0.0001)\end{array}$ & $\mathrm{N}$ \\
\hline Primocane diameter $2011(\mathrm{~mm})$ & 12.69 & 11.79 & 11.83 & 11.57 & 10.82 & 10.77 & 10.21 \\
\hline $\mathrm{C}_{\mathrm{obs}}$ & 0.00 & 7.16 & 6.77 & 8.83 & 14.79 & 15.16 & 19.56 \\
\hline $\mathrm{C}_{\mathrm{exp}}$ & & & & & 13.45 & 15.36 & 15.01 \\
\hline $\begin{array}{l}\text { Type of interaction } \\
(P \text { value })\end{array}$ & & & & & $\mathrm{N}$ & $\mathrm{N}$ & $\mathrm{N}$ \\
\hline Primocane diameter $2012(\mathrm{~mm})$ & 10.51 & 9.94 & 10.09 & 10.57 & 9.36 & 10.10 & 9.92 \\
\hline $\mathrm{C}_{\mathrm{obs}}$ & 0.00 & 5.42 & 3.98 & -0.55 & 10.92 & 3.91 & 5.63 \\
\hline $\mathrm{C}_{\text {exp }}$ & & & & & 9.18 & 4.90 & 3.45 \\
\hline $\begin{array}{l}\text { Type of interaction } \\
(P \text { value })\end{array}$ & & & & & $\mathrm{N}$ & $\mathrm{N}$ & $\mathrm{N}$ \\
\hline Fruit weight $2011(\mathrm{~g})$ & 3.35 & 2.74 & 2.87 & 2.44 & 2.33 & 2.56 & 2.08 \\
\hline $\mathrm{C}_{\mathrm{obs}}$ & 0.00 & 18.27 & 14.45 & 27.29 & 30.49 & 23.44 & 37.77 \\
\hline & & & & & 30.09 & 40.58 & 37.80 \\
\hline $\begin{array}{l}\text { Type of interaction } \\
(P \text { value })\end{array}$ & & & & & $\mathrm{N}$ & $\begin{array}{l}\text { Antagonist } \\
(<0.0001)\end{array}$ & $\mathrm{N}$ \\
\hline Fruit weight $2012(\mathrm{~g})$ & 3.68 & 3.26 & 3.26 & 2.90 & 2.85 & 3.09 & 2.65 \\
\hline $\mathrm{C}_{\mathrm{obs}}$ & 0.00 & 11.54 & 11.30 & 21.28 & 22.69 & 15.95 & 27.93 \\
\hline $\mathrm{C}_{\text {exp }}$ & & & & & 21.54 & 30.36 & 30.18 \\
\hline $\begin{array}{l}\text { Type of interaction } \\
(P \text { value })\end{array}$ & & & & & $\mathrm{N}$ & $\begin{array}{l}\text { Antagonist } \\
(<0.001)\end{array}$ & $\mathrm{N}$ \\
\hline Drupelet count 2011 & 89.46 & 83.91 & 84.00 & 62.09 & 79.82 & 76.18 & 60.18 \\
\hline $\mathrm{C}_{\mathrm{obs}}$ & 0.00 & 6.20 & 6.10 & 30.59 & 10.77 & 14.84 & 32.72 \\
\hline $\mathrm{C}_{\text {exp }}$ & & & & & 11.92 & 34.89 & 34.82 \\
\hline $\begin{array}{l}\text { Type of interaction } \\
(P \text { value })\end{array}$ & & & & & $\mathrm{N}$ & $\begin{array}{l}\text { Antagonist } \\
(<0.001)\end{array}$ & $\mathrm{N}$ \\
\hline Drupelet count 2012 & 82.78 & 85.11 & 84.61 & 61.17 & 78.89 & 76.89 & 62.56 \\
\hline $\mathrm{C}_{\mathrm{obs}}$ & 0.00 & -2.82 & -2.22 & 26.11 & 4.70 & 7.11 & 24.43 \\
\hline $\mathrm{C}_{\text {exp }}$ & & & & & -5.10 & 24.02 & 24.47 \\
\hline $\begin{array}{l}\text { Type of interaction } \\
(P \text { value })\end{array}$ & & & & & $\begin{array}{l}\text { Antagonist } \\
(0.0006)\end{array}$ & $\begin{array}{l}\text { Antagonist } \\
(<0.0001)\end{array}$ & $\mathrm{N}$ \\
\hline Firmness 2011 (g) & 68.28 & 58.61 & 62.57 & 54.31 & 59.39 & 60.15 & 46.17 \\
\hline $\mathrm{C}_{\mathrm{obs}}$ & 0.00 & 14.16 & 8.36 & 20.46 & 13.02 & 11.91 & 32.38 \\
\hline $\mathrm{C}_{\text {exp }}$ & & & & & 21.34 & 31.72 & 27.11 \\
\hline $\begin{array}{l}\text { Type of interaction } \\
(P \text { value })\end{array}$ & & & & & $\mathrm{N}$ & $\begin{array}{l}\text { Antagonist } \\
(<0.0001)\end{array}$ & $\begin{array}{l}\text { Synergistic } \\
(0.04)\end{array}$ \\
\hline Firmness 2012 (g) & 50.30 & 49.39 & 59.99 & 43.39 & 46.98 & 49.57 & 39.62 \\
\hline $\mathrm{C}_{\mathrm{obs}}$ & 0.00 & 1.81 & -19.27 & 13.74 & 6.59 & 1.44 & 21.22 \\
\hline $\mathrm{C}_{\text {exp }}$ & & & & & -17.11 & 15.30 & -2.88 \\
\hline $\begin{array}{l}\text { Type of interaction } \\
(P \text { value })\end{array}$ & & & & & $\begin{array}{l}\text { Antagonist } \\
(0.0037)\end{array}$ & $\begin{array}{l}\text { Antagonist } \\
(<0.0001)\end{array}$ & $\begin{array}{l}\text { Antagonist } \\
(0.0003)\end{array}$ \\
\hline
\end{tabular}

a RLMV: Raspberry leaf mottle virus, RpLV: Raspberry latent virus, RBDV: Raspberry bushy dwarf virus. $\mathrm{C}_{\mathrm{obs}}$ : Observed percentage reduction from healthy treatment. $\mathrm{C}_{\text {exp }}$ : Expected percentage reduction from healthy treatment. The type of interaction and the associated $P$ value are shown. $\mathrm{N}$ indicates no significant interaction $(P>0.05)$. Note that negative values in Cobs and/or Cexp were obtained for virus treatments with measured effects greater than the control. 


\section{Discussion}

Meeker, currently the most widely planted red raspberry cultivar in the PNW, is particularly susceptible to crumbly fruit caused by RBDV. The disease has resulted in significant economic losses to growers due to the low prices they get for poor quality fruit, reduced fruit yields, increased harvesting costs, and costs associated with replanting infected fields $(12,45)$. In recent years, the severity of crumbly fruit and yield decline has been more prevalent in northern Washington and British Columbia compared to southern Washington and Oregon (R. R. Martin, personal observation). Additionally, populations of the vector A. agathonica are typically greater in northern Washington, suggesting that additional aphidtransmitted viruses could be involved in crumbly fruit and yield decline. Results from virus surveys conducted in this study support those observations, as it was found that RLMV and RpLV were more common in northern Washington than in southern Washington or Oregon (Table 2). Furthermore, virus surveys from northern Washington fields showing severe crumbly fruit also had high incidences of RBDV (100\%), RLMV (100\%), and RpLV (40\%) (Table 2).

The importance of multiple viruses in causing symptoms was supported by results from our field experiment where crumbly fruit was more severe (severity score $=2$ and 3 ) in plants infected with $\mathrm{RBDV}+\mathrm{RLMV}+\mathrm{RpLV}$ and the combination RBDV+RpLV. Fruit from plants infected with the combination RBDV+RpLV and all three viruses also had the lowest berry weight and least firmness, with values significantly lower than with RBDV alone. RBDV and RBDV+RpLV infections had the lowest drupelet counts, although no statistical differences were observed between these two groups of plants. It seems that the crumbly phenotype observed in plants infected with RBDV+RpLV and RBDV+RLMV+RpLV might be related to a reduction in drupelet cohesion (firmness) and drupelet weight, but not to a reduction in drupelet number per se.

All infected treatments had lower primocane height; however, treatments co-infected with RBDV+RLMV, RBDV+RpLV, and $\mathrm{RBDV}+\mathrm{RLMV}+\mathrm{RpLV}$ had the greatest reductions in primocane height compared to healthy controls. The differences were more pronounced during the establishment year, where primocane length was reduced 76 and $70 \%$ in plants co-infected with RBDV+RLMV and RBDV+RpLV+RLMV, respectively, compared to the control. It appears that physiological effects caused by virus infections were more severe during the establishment phase than in subsequent years. This may be explained by stress associated with adaptation to field conditions during the planting year that exacerbate the stress of virus infections (35).

Synergistic interactions have been reported based on increased symptom severity in plants co-infected with more than one virus compared to singly infected plants $(11,39,42)$. Because RBDV, RLMV, and RpLV each had an effect on plant growth and fruit parameters measured here, a statistical approach was used to deter- mine whether the observed symptoms were the product of interactions between the co-infecting viruses. Further, the nature of any interaction (synergistic or antagonistic) was determined. Significant antagonistic interactions were observed between RBDV and RLMV for all the fruit parameters measured during 2011 and 2012. However, qRT-PCR experiments showed a 400-fold increase in RBDV titers in the presence of RLMV. It appears that this phenomenon does not have an impact on fruit weight, firmness, and drupelet count.

Comparisons of virus titers across treatments under field and greenhouse conditions supported the finding reported by QuitoAvila and Martin (30) that the titer of RBDV was increased approximately 400-fold in plants co-infected with RLMV or RLMV+RpLV relative to the titer in plants infected with RBDV alone. The significant increase in titer of RBDV in the presence of RLMV in the field was similarly found in greenhouse experiments, suggesting that environmental conditions, i.e., light and temperature, do not have a direct impact on this virus interaction.

qRT-PCR also showed a slight titer increase (22-fold compared to the initial titer at the beginning of the season) of RLMV in August both in single and mixed infections. There were no titer changes of RBDV or RpLV throughout the season. However, each virus was readily detected throughout the growing season, which is of significance from a management standpoint because sampling for virus testing could be done throughout the growing season.

This study reports for the first time the effect of RLMV and RpLV on primocane growth and fruit weight in red raspberry Meeker. Virus combinations involving RBDV+RpLV or RBDV+RLMV+RpLV exhibited the greatest increase in crumbly fruit and the reduction of berry weight. Additionally, the increase in fruit crumbliness observed in plants co-infected with $\mathrm{RBDV}+\mathrm{RpLV}$ or $\mathrm{RBDV}+\mathrm{RLMV}+\mathrm{RpLV}$ was not produced by synergistic interactions between the viruses at the replication level. Since RBDV is transmitted by pollen, management should focus on controlling A. agathonica to reduce the incidence of RLMV and RpLV (16); more importantly, producers should plant certified virus-tested material since primocane symptoms were greatest during the establishment year.

\section{Acknowledgments}

This study was partially funded by the United States Department of Agriculture under the Specialty Crops Research Initiative (SCRI), award number 200951181-06022, CRIS 5358-22000-032-00D. We thank people of the Northwestern Research and Extension Center in Mt. Vernon, Washington, particularly Gary Moulton and Tom Walters for their unconditional support in the execution of field work. Likewise, we express our special grattitude to raspberry growers in Washington and Oregon, especially Randy Hancoop and Rader's Farms for allowing us to use their fields to conduct surveys and virus monitoring.

\section{Literature Cited}

1. Barker, H. 1987. Invasion of non-phloem tissue in Nicotiana clevelandii by Potato leafroll luteovirus is enhanced in plants also infected with Potato $Y$

Table 2. Virus survey in Washington and Oregon ${ }^{\mathrm{a}}$

\begin{tabular}{|c|c|c|c|c|c|c|c|}
\hline & \multirow[b]{2}{*}{$\begin{array}{l}\text { Field age } \\
\text { (years) }\end{array}$} & \multicolumn{2}{|c|}{ RLMV (\%) } & \multicolumn{2}{|c|}{ RpLV (\%) } & \multicolumn{2}{|c|}{ RBDV (\%) } \\
\hline & & $\begin{array}{c}\text { Prevalence } \\
n=4\end{array}$ & $\begin{array}{c}\text { Incidence } \\
n=36\end{array}$ & $\begin{array}{c}\text { Prevalence } \\
n=4\end{array}$ & $\begin{array}{c}\text { Incidence } \\
n=36\end{array}$ & $\begin{array}{c}\text { Prevalence } \\
n=4\end{array}$ & $\begin{array}{c}\text { Incidence } \\
n=36\end{array}$ \\
\hline \multirow[t]{7}{*}{ Northern Washington } & 1 & 100 & $4-30$ & 0 & 0 & 0 & 0 \\
\hline & 2 & 75 & $6-58$ & 25 & 21 & 100 & $12-18$ \\
\hline & 3 & 100 & $6-50$ & 25 & 6 & 100 & $25-35$ \\
\hline & 4 & 100 & $13-19$ & 50 & $4-8$ & 100 & $70-85$ \\
\hline & 5 & 100 & $44-100$ & 50 & $23-63$ & 100 & $88-98$ \\
\hline & 6 & 100 & $70-100$ & 100 & $7-20$ & 100 & $97-100$ \\
\hline & 7 & 100 & $80-100$ & 100 & $8-30$ & 100 & 100 \\
\hline Southern Washington & 1 & 0 & 0 & 0 & 0 & 0 & 0 \\
\hline \multirow[t]{4}{*}{ and Oregon } & 5 & 100 & $40-74$ & 100 & $10-20$ & 100 & $89-95$ \\
\hline & 6 & 0 & 0 & 100 & $15-35$ & 100 & $90-98$ \\
\hline & 7 & 100 & $19-40$ & 100 & $17-20$ & 100 & $84-94$ \\
\hline & 8 & 100 & $20-23$ & 0 & 0 & 100 & 100 \\
\hline
\end{tabular}

a Prevalence indicates the percentage of tested fields $(n=4)$ with at least one positive for the virus. Incidence indicates the percentage of tested plants $(n=$ 36) positive for the virus. The lowest and highest incidence found for each age-class is shown. 
potyvirus. J. Gen. Virol. 68:1223-1227.

2. Barritt, B. H., Torre, L. H., Pepin, H. S., and Daubeny, H. A. 1980. Fruit firmness measurement in red raspberry. HortScience 15:38-39.

3. Calvert, L. A., and Ghabrial, S. A. 1983. Enhancement by Soybean mosaic virus of Bean pod mottle virus titer in doubly infected soybean. Phytopathology 73:992-997.

4. Cao, X., Zhou, P., Zhang, X., Zhu, S., Zhong, X., Xiao, Q., Ding, B., and Li, Y. 2005. Identification of an RNA silencing suppressor from a plant double-stranded RNA virus. J. Virol. 79:13018-13027.

5. Choi, S. K., Yoon, J. Y., Ryu, K. H., Choi, J. K., Palukaitis, P., and Park, W. M. 2002. Systemic movement of a movement-deficient strain of Cucumber mosaic virus in zucchini squash is facilitated by a cucurbit infecting potyvirus. J. Gen. Virol. 83:3173-3178.

6. Converse, R. H. 1973. Occurrence and some properties of Raspberry bushy dwarf virus in Rubus species in the United States. Phytopathology 63:780-783.

7. Cooper, B., Schmitz, I., Rao, A. L., Beachy, R. N., and Dodds, J. A. 1996. Cell-to-cell transport of movement-defective cucumber mosaic and tobacco mosaic viruses in transgenic plants expressing heterologous movement protein genes. Virology 216:208-213.

8. Dasgupta, R., Garcia, B. H., and Goodman, R. M. 2001. Systemic spread of an RNA insect virus in plants expressing plant viral movement protein genes. Proc. Natl. Acad. Sci. 98:4910-4915.

9. Daubeny, H., Freeman, J., and Stace-Smith, R. 1982. Effects of Raspberry bushy dwarf virus on yield and cane growth in susceptible red raspberry cultivars. HortScience 17:645-647.

10. Dufresne, D. J., Valverde, R. A., and Hobbs, H. A. 1999. Effect of co-infections of Andean potato mottle comovirus with two potyviruses in seven Capsicum genotypes. Rev. Mex. Fitopatol. 17:17-22.

11. García-Cano, E., Resende, R. O., Fernández-Muñoz, R., and Moriones, E. 2006. Synergistic interaction between Tomato chlorosis virus and Tomato spotted wilt virus results in breakdown of resistance in tomato. Phytopathology 96:1263-1269.

12. Gianessi, L. P., Silvers, C. S., Sankula, S., and Carpenter, J. E. 2002. Raspberry crumbly fruit. Pages 2-9 in: Current and Potential Impact for Improving Pest Management in U.S. Agriculture. National Center for Food and Agricultural Policy, Washington, DC.

13. Halgren, A., Tzanetakis, I. E., and Martin, R. R. 2007. Identification, characterization, and detection of Black raspberry necrosis virus. Phytopathology $97: 44-50$.

14. Hu, W. W., Wong, S. M., Loh, C. S., and Goh, C. J. 1998. Synergism in replication of Cymbidium mosaic potexvirus (CymMV) and Odontoglossum ringspot tobamovirus (ORSV) RNA in orchid protoplasts. Arch. Virol. 143:1265-1275.

15. Karyeija, R. F., Kreuze, J. F., Gibson, R. W., and Valkonen, J. P. 2000. Synergistic interactions of a potyvirus and a phloem-limited crinivirus in sweet potato plants. Virology 269:26-36.

16. Lightle, D. 2013. Interactions of Amphorophora agathonica Hottes with raspberry viruses and resistant red and black raspberry. Ph.D. diss. Oregon State University, Corvallis.

17. Littell, R. C., Milliken, G. A., Stroup, W. W., Wolfinger, R. D., and Schabenberger, O. 2006. SAS for Mixed Models, 2nd ed. SAS Institute Inc., Cary, NC.

18. Martin, R. R. 1999. Raspberry viruses in Oregon, Washington and British Columbia. Acta Hortic. 505:259-262.

19. Martin, R. R., MacFarlane, S., Sabanadzovic, S., Quito-Avila, D. F., Poudel, B., and Tzanetakis, I. E. 2013. Virus and virus diseases of Rubus. Plant Dis. 97:168-182.

20. McGavin, W. J., and MacFarlane, S. A. 2010. Sequence similarities between Raspberry leaf mottle virus, Raspberry leaf spot virus and the closterovirus Raspberry mottle virus. Ann. Appl. Biol. 156:439-448.

21. Murant, A. F., Chambers, J., and Jones, A. T. 1974. Spread of Raspberry bushy dwarf virus by pollination, its association with crumbly fruit and problems of control. Ann. Appl. Biol. 77:271-281.

22. Murphy, J. F., and Bowen, K. L. 2006. Synergistic disease in pepper caused by the mixed infection of Cucumber mosaic virus and Pepper mottle virus. Phytopathology 96:240-247.

23. Niblett, C. L., and Claflin, L. E. 1978. Corn lethal necrosis, a new virus disease of corn in Kansas. Plant Dis. Rep. 62:15-19.

24. Pfaffl, M. W. 2001. A new mathematical model for relative quantification in real-time RT-PCR. Nucleic Acids Res. 9:29.

25. Poolpol, P., and Inouye, T. 1986. Enhancement of cucumber mosaic virus multiplication by zucchini yellow mosaic virus in doubly infected cucumber plants. Ann. Phytopathol. Soc. Jpn. 52:22-30.

26. Pruss, G., Ge, X., Shi, X. M., Carrington, J. C., and Vance, V. B. 1997. Plant viral synergism: The potyviral genome encodes a broad-range pathogenicity enhancer that transactivates replication of heterologous viruses. Plant Cell 9:859-868

27. Quito-Avila, D. F., Jelkmann, W., Alt, S., Leible, S., and Martin, R. R. 2010 A new member of the family Reoviridae may contribute to severe crumbly fruit in red raspberry, Rubus idaeus 'Meeker'. Pages 18-23 in: Proc. 21st Int. Conf. Virus Graft Transmiss. Dis. Fruit Crops ICVF.

28. Quito-Avila, D. F., Jelkmann, W., Tzanetakis, I., Keller, K., and Martin, R. R. 2011. Complete sequence and genetic characterization of Raspberry latent virus, a novel member of the family Reoviridae. Virus Res. 55:397-405.

29. Quito-Avila, D. F., Lightle, D., Lee, J., and Martin, R. R. 2012. Transmission biology of Raspberry latent virus, the first aphid-borne reovirus. Phytopathology 102:547-553.

30. Quito-Avila, D. F., and Martin, R. R. 2012. Real-time RT-PCR for detection of Raspberry bushy dwarf virus, Raspberry leaf mottle virus and characterizing synergistic interactions in mixed infections. J. Virol. Methods 179:38-44

31. Rochow, W. F., and Ross, F. 1955. Virus multiplication in plants doubly infected by potato viruses $\mathrm{X}$ and $\mathrm{Y}$. Virology 1:10-27.

32. Rott, M. E., and Jelkmann, W. 2001. Characterization and detection of several filamentous viruses of cherry: Adaptation of an alternative cloning method (DOP-PCR), and modification of an RNA extraction protocol. Eur. J. Plant Pathol. 107:411-420.

33. SAS Institute. 2008. GLIMMIX User's Manual, version 9.2. SAS Institute, Cary, NC.

34. Scheets, K. 1998. Maize chlorotic mottle machlomovirus and Wheat streak mosaic rymovirus concentrations increase in the synergistic disease corn lethal necrosis. Virology 242:28-38.

35. Suntio, T., and Makinen, K. 2012. Abiotic stress responses promote Potato virus $A$ infection in Nicotiana benthamiana. Mol. Plant Pathol. 13:775-784.

36. Susaimuthu, J., Tzanetakis, I. E., Gergerich, R. C., Kim, S. K., and Martin, R. R. 2008. Viral interactions lead to decline of blackberry plants. Plant Dis. 92:1288-1292.

37. Susaimuthu, J., Tzanetakis, I. E., Gergerich, R. C., and Martin, R. R. 2008 A member of a new genus in the Potyviridae infects Rubus. Virus Res.131:145-151.

38. Tzanetakis, I. E., Halgren, A., Mosier, N., and Martin, R. R. 2007. Identification and characterization of Raspberry mottle virus, a novel member of the Closteroviridae. Virus Res. 127:26-33.

39. Untiveros, M., Fuentes, S., and Salazar, L. F. 2007. Synergistic interaction of Sweet potato chlorotic stunt virus (Crinivirus) with carla-, cucumo-, ipomo-, and potyviruses infecting sweet potato. Plant Dis. 91:669-676.

40. Vance, V. B. 1999. Synergism: Plant viruses. Vol. 39, pages 1694-1699 in: Encyclopedia of Virology, 2nd ed. A. Granoff and R. G. Webster, eds. Academic Press, San Diego, CA.

41. Voinnet, O., Pinto, Y. M., and Baulcombe, D. C. 1999. Suppression of gene silencing: A general strategy used by diverse DNA and RNA viruses of plants. Proc. Natl. Acad. Sci. USA 96:14147-14152.

42. Wang, Y., Gaba, V., Yang, J., Palukaitis, P., and Gal-On, A. 2002. Characterization of synergy between Cucumber mosaic virus and potyviruses in cucurbit hosts. Phytopathology 92:51-58.

43. Wintermantel, W. M. 2005. Co-infection of Beet mosaic virus with beet yellowing viruses leads to increased symptom expression on sugar beet. Plant Dis. 89:325-331.

44. Wintermantel, W. M., Cortez, A. A., Anchieta, A. G., Gulati-Sakhuja, A., and Hladky, L. L. 2008. Co-infection by two criniviruses alters accumulation of each virus in a host-specific manner and influences efficiency of virus transmission. Phytopathology 98:1340-1345.

45. Wolford, E. 1967. Observations on the 'Meeker' raspberry for freezing and preserving. Proc. West. Wash. Hortic. Assoc. 57:69-70. 